\title{
Education as a Tool for Empowering Kenya's Street Children for Integration in National Development
}

\author{
Martin C. Njoroge
}

\begin{abstract}
Education is an empowering process that enables those who have been marginalized in the social, economic, political and cultural spheres to claim their status as fully participating members of the society. Nevertheless, about 300,000 street children in Kenya have had no formal education and are not proficient in the two languages used - English (official language) and Swahili (national language)- languages in which vital information leading to improved livelihoods and participation in national development is available. Drawing evidence from an ongoing study on the literacy and numeracy needs of street children in Kenya, I argue that street children need to be equipped with appropriate knowledge through acquisition of numeracy, language and literacy skills for them to be fully empowered to be able to participate in the country's development.
\end{abstract}

\section{Introduction}

The survival of a nation in the present world depends on that nation's knowledge of the environment, its economic output, the technical skills of its population in the areas of agriculture, land use, human rights, tourism and the knowledge of information technologies in order that the nation may gain easy access to global knowledge. To attain all this, the country must focus on achieving education for all citizens for it is only through education that these great goals can be achieved.

Education is a cornerstone to successful life and for survival of children in the real world. Indeed as an American educationist, J. Gibbs (2004) observes, education is the principal instrument in awakening the child to cultural values and preparing him/her for later professional training and in helping him/her to adjust normally to his/her environment. In these days, it is doubtful that any child may reasonably be expected to succeed in life if he or she is denied the opportunity of an education. Yet education is something that is often lost to the street children and other children in extremely difficult circumstances in Kenya as well as in the rest of the world.

A group that requires our attention in terms of empowerment, linguistic or otherwise, comprises children in extremely difficult circumstances. Street children, whom I focus on in this paper, fall within this category. 


\section{Education, Language and Empowerment}

The development of a nation is not possible unless it affects all members of the society. On the one hand, education and acquisition of knowledge are crucial in empowerment and development of a community. Education empowers one to take advantage of life's opportunities and it is an indispensable vehicle to development and quality living. Education brings greater economic growth, lower crime rates, and improved social services. Conversely, ignorance is the biggest obstacle to fight against poverty.

On the other hand, there is no effective education without language: - thus, language is one of the essential ingredients for nationhood. The available literature notes that language is the most relevant tool for building knowledge and know-how of a country's citizenry (Beneitez, 2002; Mugo, 2004). In addition, language is a living expression of one's cultural identity and it is seen as a key factor in economic development.

At the same time, we cannot empower a community without a language. The street children are not literate in either English or Swahili, languages in which vital information leading to improved livelihoods is available. The fact that street children do not have proficiency in the two main languages in Kenya deprives them of advantageous knowledge. The street children need literacy and numeracy skills to be able to benefit from an education about the world around them.

The street children suffer economic discrimination in various forms. The working street children are paid very poorly for their services. Further, they are not well informed on how to properly manage their time or access to good markets for the products that they make like carvings and necklaces. Such inability could be because they cannot speak English or standard Swahili, thus must use middlemen to act as go-betweens, and these interpreters sometimes take advantage of the street children. Moreover, accessibility and availability of natural and new technological resources and knowledge about their control and management, as well as new market and productive techniques available for the street children are usually hard to come by, even without linguistic disadvantages.

This paper argues that all citizens in a country should be prepared accordingly to be able to participate in national development, because it is their right. In addition, without their participation, there would be no development, and any development in the nation will not be sustained. The governments should facilitate everyone's participation because as communities become stronger, they contribute to national development.

Empowerment involves giving people the opportunity to gain control over their own destiny through access to education, jobs and private property. Thus empowerment is geared at strengthening a group rather than encouraging it to remain dependent upon outside resources. 


\section{Literature Review}

\section{Street children: Definition and Characteristics}

Schurink (1993) as cited in Grundling \& Grundling (2006) define a street child as a boy or a girl who is under the age of 18 and whom left his/her home environment part time or permanently because of problems at home or at school and who spends most of his/her time unsupervised on the street as a subculture of children who live an unprotected communal life and who depend on themselves and on each other, and not on adult for the provision of physical and emotional needs such as food, clothing, nurturance, direction and socialization.

Dallape (1987) captures the reality of the world's street children. They live alone; are undernourished since birth; are denied affection, education and help; live without love; survive by expedience, by theft and by violence; coalesce into gangs and reinvent a family, a structure they have never known. They are children who are used unscrupulously by others, mistreated, imprisoned, and even eliminated; children whom the world tries to forget or ignore; children who see grown-ups as their enemies; children nobody comforts. Tomorrow, these street children will be men and women.

Several approaches have been adopted in addressing the plight of the street children all over the world: charity, integration, rehabilitation and community based. Charity approach aims at giving gifts to the children, thus temporarily alleviating the need. However, charity approach does not help the children to become self reliant, but instead makes the children more dependent upon the giver. Thus poverty is still sustained.

\section{Street Children Phenomenon in Kenya}

The problem of street children still remains among the greatest challenges facing the people and the government of Kenya (Mugo 2004). The phenomenon of street children in Kenya dates back to the colonial days (between 1920 and 1963). Further, with the emergence of large urban centers, street children have now become a part of the new development. It is estimated that Kenya has over 300,000 street children (UNICEF, 2000).

Several factors lead children to leave their homes and migrate to the streets of large urban centers: war and conflict, abuse and neglect, domestic violence, single parenthood, the AIDS pandemic, loss of parental control, rebellion, weakening of traditional family systems, orphan-hood and poverty. Coupled with these factors is the fact that majority of the street children come from large families with severe financial hardships. Half a million children in Kenya today have lost contact with their families as a result of these factors. Such children are currently living under very difficult circumstances as orphans, refugees, child laborers and street children. As these children grow up, the girls gradually drift into prostitution while boys tend to become hardcore criminals if nothing is done to rehabilitate them. 
With the current volatile situation in Kenya following the disputed 2007 presidential elections, one major town in Kenya, Naivasha, is reported to be bursting at the seams with street children and even adults ${ }^{1}$. The children station themselves at major shops soliciting for alms from shoppers, while others survive on dumpsites from which they forage for food. They beg, bowl in hand. They are about 400 in a base they call Salmonde, and have a leader, Pilato. They openly smoke bhang without fear of arrest. This scenario is replicated in all urban centers in Kenya.

\section{Key Factors}

Poverty has been cited as one of the main push factors that drive children to the streets and the migration trends are enhanced by increased globalization (Mugo 2004). The effects of absolute poverty in families are usually dehumanizing and devastating. Poverty affects not only the family and the community, but also the physiological well being of the child. Older siblings in poor families must care for the younger ones and they often find themselves pulled to the urban centers in the hope of finding greater opportunities.

Abuse and mistreatment is also a major cause that drives children to the streets. Above this is the impact on HIV/AIDS on the family and society in general. Many children are left orphans and in abject poverty. The disease continues to attack the most productive age groups among the population, thus rendering many without one or more parents and adding to the stress to grandparents who have to support growing numbers of orphans. The children, seeing the situation they are in, think of alternative means of supporting themselves and go to the streets. Thus, the connection between HIV/AIDS, poverty, abuse and homelessness has been documented as contributing to flow of children to the streets (Mugo, 2004).

\section{Life on the Streets}

Street children in Kenya and elsewhere, beg, scavenge in garbage heaps to collect rags, paper, plastic and bottle caps to earn some money for food and clothing. Majority of them work and even live their entire life on urban streets struggling with ignorance, abuse, exploitation and neglect of adults who should in reality be their protectors and their guardians. Yet despite all this, they are both heroic in their quest for a better life and quietly prophetic of a tragic tomorrow if we do not defend their rights and respond to their needs. Their message often goes unheard and their lives go untouched as the government plans and initiates programs of community development, urban basic services and international cooperation (Dallape, 1987). The urban societies treat them as social outcasts and for this reason, the street children mistrust society and look at any outsider or stranger with suspicion. The public uses words such as hooligans, delinquent and vagrant to describe the street children (Ayuku, 2001). Alienated and insulted by society, the children suffer from low selfesteem despite their considerable achievements in surviving in the face of terrible odds. 
As Mugo (2004) observes, the eventual solution to the never-ending dilemma in the streets lies in prevention - at the heart of every community and in the conscience of every society- and asks us all to work together upon this long term agenda as well as within our local hands-on with the street children themselves. It should be a common cause that we should all come together for. If we were to do so, the problem facing the children of the street would surely remain silent anymore.

A proportion of street children have lost contact with their families, sometimes because they are not wanted, sometimes because they are not wanted, sometimes because 'home' is so distressing they have left on their own accord. Many engage in risky behaviour, developing a sub-culture of their own and adopting the street as both a workplace and habitat. Divorced from a stable social environment, these street children easily descend into petty thieving, which often develops into more serious criminality.

Contrary to common beliefs, street children are not always harmful and maladjusted; some street children have been identified to possess sound and healthy personalities. Aptekar (1996) observes that street children are not lazy and idle as many think. Some of them work and survive by justifiable income-earning methods such as car washing and errand running. They also have identifiable abodes and families in form of street groups, and they only live and work on defined territories. This shows that these are fully functioning human beings.

\section{Stigmatized Children}

The street child in Kenya has been stigmatized. He is called a thief, a prostitute, public menace, idler and the like and such social labels belie the behavioural complexity and personal variation behind each street child. Swart-Kruger (1996:202) reports of a street boy who felt that people did not want to see street children; that it was as if they were a bad dream... felt that people did not love them; that they treated them worse than animals. The boy added that such people forget that the street children are people too, with feelings. Such feelings show that the street children feel alienated from the rest of the society. They feel that the society does not care whether they die or live. There is need for mutual understanding and communication between the two parties and language should play a significant role.

Apteker (1996) observes that street children all over the world are treated badly and that they have been sold into what amounts as servitude and have been murdered for no more than committing petty crimes or simply being naughty. Boyden, as cited in Apteker (1996), puts forward the idea that street children become the objects of moral judgment because they violate the norms of society by not being under the same roof as their parents, by working instead of being in school, and by assuming the right to enjoy the fruits of their work as they choose (consuming drugs or alcohol). But is this indeed the case? 
Martin C. Njoroge 249

In Kenya, as elsewhere, street children have come to represent the moral decay and large-scale social problems in the society, including inequality of income, and changing family values. As Lugalla and Kibasa (2003) note, when people look into the eyes of impoverished street and working children in Kenya, they are confronted by the breakdown of their society and insecurity of their future. Thus, there are many suspicions and misunderstandings between street children and the wider society.

A starting point to start bridging the gap will be inculcation of linguistic skills in both English and Kiswahili, which will connect the street children with the wider society. These skills include: listening, speaking, reading and writing (Bukenya et al., 2005). The acquisition of, for example, listening and speaking skills in the two language will help street children create a favorable impression of themselves and will be able to interact with others effectively and confidently. In addition, reading may expose street children to new vocabulary, good models of language use, different registers and learning of concepts thus widening the horizons of the street children. Designing a language curriculum that focuses on the acquisition of the four language skills in both English and Kiswahili followed by teaching of other subjects would be a milestone in narrowing the gap between the public and the street children.

\section{Informational and Educational Empowerment}

Kenya spells out her national goals of education through which her aspirations are met (Government of Kenya 2006). One of the goals listed in the manual is to promote social, economic, technological and industrial needs for national development. This means that education in Kenya should:

- $\quad$ Prepare children for the changes in attitude and relationships, which are necessary for the smooth process of a rapidly developing modern economy.

- $\quad$ Produce citizens with skills, knowledge, expertise and personal qualities that are required to support a growing economy.

- Provide learners with the necessary skills, knowledge and attitudes for industrial development.

These objectives relate very well to the objectives of primary education of which most street children do not get. But how do the street children achieve the aforementioned? Where do they come in so that they too can be prepared to participate in nation building? Something needs to be done to address their literacy and numeracy needs, hence the proposal of an Education for Life Center. 
Literacy and Numeracy Needs of Kenya's Street Children

The street children need to be equipped with the ability to read and write. After achieving this milestone in their lives, they will be able to access relevant information and technology which will facilitate their being recognized as important and vital citizens in the society. Thus they will be able to function effectively in the society because they will have benefited from an education about the world around them.

A great number of the street children in Kenya have never been to school or dropped out in their first years of primary learning (Njoroge, in progress). Despite this finding, data analysis indicates that what street children in Kenya really crave for most from education is literacy and numeracy. The desire to learn is there and the need to be literate too. They all understand that some kind of know-how is essential for their future life. The children would like to have a full education and lead a 'normal' life like their peers in the regular schools. They know that literacy and numeracy skills are valuable in enabling them calculate the profits of their imagined future businesses, use of money, how to save and where to save.

Most of the street children interviewed were enthusiastic about going back to school and had great aspirations of where and what they wish to be in future. Some were interested in becoming pilots, doctors, security officers, pastors, carpenters, masons and mechanics. They felt that if they were able to read and write, and do some simple calculations, they would do much better in life. They understood their predicament in trying to communicate in a Kenyan society that usually talks through written communication and uses English and Swahili as the medium of communication. Further, some would love to read the Bible, while others would want to watch and understand some television documentaries but their major handicap is literacy.

\section{A few examples from Data Analysis}

\section{A. Allan}

He is fourteen years old boy, originally from Siaya District in the western region of Kenya. His father worked in the quarry. He traveled to Nairobi with his aunt, who lives in Mathare, one of Kenya's biggest slums. He found life in the slums very difficult so he ran away and moved to the streets upon the influence of a fellow slum boy he befriended in Mathare. On the streets, Allan started begging money and some other time he would collect waste paper and sell to get money for food. He now lives on the streets and reckons that on the life is very hard. He has three sisters whom he has not seen them in a long time. He cannot read the Bible, yet he loves to read of the word of God. He can only watch Karate movies because they have actions as he cannot understand the language because most programs are in English. 


\section{Aspirations}

Allan wants to be a mechanic, to repair cars. Before doing so, he would love to study up to high school. After that he would then look for a job and think of how to help his parents and siblings. He would like to get married, have three children, live happily and comfortably as a family, have the children go to good schools. He would love to learn more about Karate so that he can learn how to defend himself from bad people such as criminals.

\section{B. Rebecca}

She was born in 1992 in Dagoretti, in the outskirts of Nairobi. She can speak Swahili and some English. Her parents separated a long time ago and the father later remarried. She has six siblings, her being fourth born. She used to live with her grandmother. She started school then dropped in Primary 3 as there was no food at home and she was to take care of the younger siblings to enable the mother go out to look for food.

\section{Aspirations}

She would love to resume school and be a lawyer so as to defend the helpless and poor ones. She developed interest in the legal affairs when she was called as a witness in her parents' divorce case when she was just 8 years old. She would love to study up to University level. She would also love to get married and have four children.

\section{Street Children's Fears}

The children also felt that most regular schools would not admit them for fear that they could not fit into the normal school routine on the account of the character change they have undergone while on the streets. In addition, they also felt that the learning they had missed out ever since leaving school (some had never been to school) would make the schools feel that it would be practically impossible for them to fit in.

There is need therefore to consider how the society can help street children who cannot be integrated directly into the regular schools due to age or other constraints, but are willing to be helped in the acquisition of literacy and numeracy skills. This then prompts the establishment of an Education for Life Center for these street children.

\section{Proposed Education for Life Center}

The proposed Education for Life Center should focus on language, literacy and numeracy needs of Kenya's street children. It should start as a pilot center. The children will be introduced to subjects such as Life skills, Social Studies, Science, English, Swahili and Mathematics. The center will aim at helping street children to grow in mind, body and spirit, hoping to help them be the best that they can, both inside and outside the center. The objective of the center will be to transform the children into fully functioning and capable global citizens, confident and 
independent, taking control and action within their own lives. It is hoped that such a center will act as a safety net for children who fall outside the regular school system. Thus, street children who cannot be mainstreamed into state school can still access education. The center will act as a bridge or a steppingstone to other avenues that the child may be interested in exploring.

With the help of the Kenyan government, specifically Children's department officers in the Ministry of Home Affairs, the center hopes to reach out to the street children with the aim facilitating their voluntary desire to relocate to a rehabilitation center in Nairobi city, where needs assessment, detailed counseling and provision of basic needs such as food, shelter, clothing and health examination will be provided for them. In case there are former street children who have already been rehabilitated and are now successful in the society, they will form part of the rehabilitative team. The team will go to the streets, train and bus stations, parks, alleys and other spots where the street children in Nairobi are found to interact with them, and with time, win their trust. The main challenge will be convincing them of a better alternative to their 'profitable' street survival activities.

After receiving counseling, the young street children and the older ones who opt to be resettled with their families and return to school will be taken to their homes. This will be after finding out what is there at home and why the particular street child left home in the first place. This would ensure the cause of separation has been dealt with first before the child is taken back home. I believe that family is the best place for a child's growth and development. There will be a follow-up to ascertain that the children do go back to school and the parents as well as the children will sign a legal bond to this effect. With the help of the area education officers, the children will be placed in neighboring primary schools.

The overage street children who remain will proceed to Education for Life Center where more counseling will be administered. This will be followed by introduction to literacy and numeracy skills as will be stipulated in the curriculum. After receiving instructions in the broad areas and got certificates, some may join vocational training colleges while others may proceed to regular schools to continue formal education, thus increasing their status within the family and in the society. After the vocational training, the learners will find their place in life through employment and selfemployment. They may end up becoming experts in leatherwork, mechanic, masonry, carpentry, cooks, tailoring, and photography, among others. Their financial empowerment will boost their often-low self-esteem as they discover their potential in the task of nation building. They will have been taught how to stand on their two feet and to participate as a member of an increasing and complicated society.

The aim of the Educational center will be to change lives of the street children and provide them with the opportunity to improve their future. Now they will have their basic needs met and will have a chance to get off drugs, access primary education 
Martin C. Njoroge 253

and even engage in income generating activities. The center will incorporate participation and behavioral changes to ensure that the program takes the desires of street life out of the children, instead of merely taking the children out of the street. The aim is to take the children off the street and provide them with a second chance: enhance their learning and learning capacities and social networks; provide them with vocational training, business skills, mentoring and avenues to existing mental and health care centers.

The center will aim at creating a learning environment that would accommodate the deviant behavior exhibited by children addicted to drugs, children who were constantly abused at home and often misused by established gangsters: terrified children who were forever on the run, fleeing the police. The center's aim is to prepare the children realistically for life, helping them to develop a constructive attitude to life and help them to understand their responsibilities as members of the community. The emphasis will be on training for self-development rather than training for certificate only. The focus will be on instilling in the children those values and attitudes necessary for adjustment to desirable living in the society.

If funds will be available, the vocational training can be built next to the center so that the children who wish to proceed to skills training can do so, and the ones who want to join regular schools can go ahead, again with the assistance of area education officers. It is hoped that by the end of the program, the children will have a working knowledge of especially English, Swahili and basic Math.

Language is a major means of thinking and communicating and it is fundamental to learning. Through language skills, the children will become articulate, self aware, effective decision makers who are able to live and work with others. Proficiency in both Swahili and English will help a great deal to build the children's self-esteem and confidence and will be an added boost in inculcating a value and desire for self development, so that they can aspire to be something better in life. Additionally, their learning English will enable them interact with people from different backgrounds. This will particularly enrich their personal growth and to facilitate international understanding. All in all, it is hoped that they will end up behaving responsibly, honestly, openly and creatively.

\section{Conclusion}

The street families and street children are indeed a marginalized lot whose needs must be addressed. Although the main task ahead should be to combat and alleviate poverty and economically empower vulnerable families currently living below the poverty line, it is imperative to consider the plight of the children already on the streets and who feel they are too old to join six year-olds in preschool in order to acquire language, literacy and numeracy skills. Being unable to break the vicious cycle among street children will condemn them to a struggle in a never-ending situation. 
The educational intervention in which the street children will acquire literacy and numeracy skills may be a cry in the wilderness, but we must be willing to be mindful of the less fortunate in the society and help in the realization of a better world for one or two street children who may benefit from the programs such as the proposed education for life center. It is the thesis of this paper that through acquisition of language, literacy and numeracy skills, street children in Kenya will be empowered and the development of their knowledge on other national development activities that facilitate integration in nation building will be inevitable.

\section{References}

ANPPCAN (1995). Hearing on street children in Kenya. Nairobi: ANPPCAN Publications.

Aptekar, L. (1996). Street children in Nairobi. Africa Insight 26, 3, pp. 20-22).

Ayuku, D. (2001). A case study of street children in Kenya. In Blumenthal, D. \& Boelen, S. (eds.). Universities and health of the disadvantaged. Geneva: World Health Organization, pp. 81-2.

Beneitez, T. (2002) Green light for street children. Brussels: ENCSCW.

Bukenya, A., Kioko, A. \& Njeng'ere, D. (2005). Head start English. Nairobi: Oxford University Press.

Dallape, F. (1987) An experience with street children in Nairobi. Nairobi: Undugu Society Publication

Donald, D. \& Swart-Kruger, J. (1994). The South African street child: Developmental implications: South African Journal of Psychology 24: 169-74.

Gibbs, J. (2004) Educating the homeless. Techniques 25

Grundling, J \& Grundling, I. (2006) The concrete particulars of the realities of street children. Human Relations 58 (2)

Habitat (1996). Children of the runaway cities. Nairobi: UN Publications.

Lugalla, J. \& Kibasa, C. (2003). Urban life and children's health. Hamburg: Lit Verlag Munster.

Mugo, J. (2004) Rehabilitation of street children in Kenya: Approaches, quality and challenges. Frankfurt: IKO- Verlag.

Njoroge, M. (in progress) Research project on literacy and numeracy of street children in Kenya.

Save the Children Sweden (2003-2004). Support and safety for street children on the streets. In Programme Profile for Eastern and Central African Region. Save the Children Sweden Publications.

UNICEF (1996). Children in especially difficult circumstances. New York: 